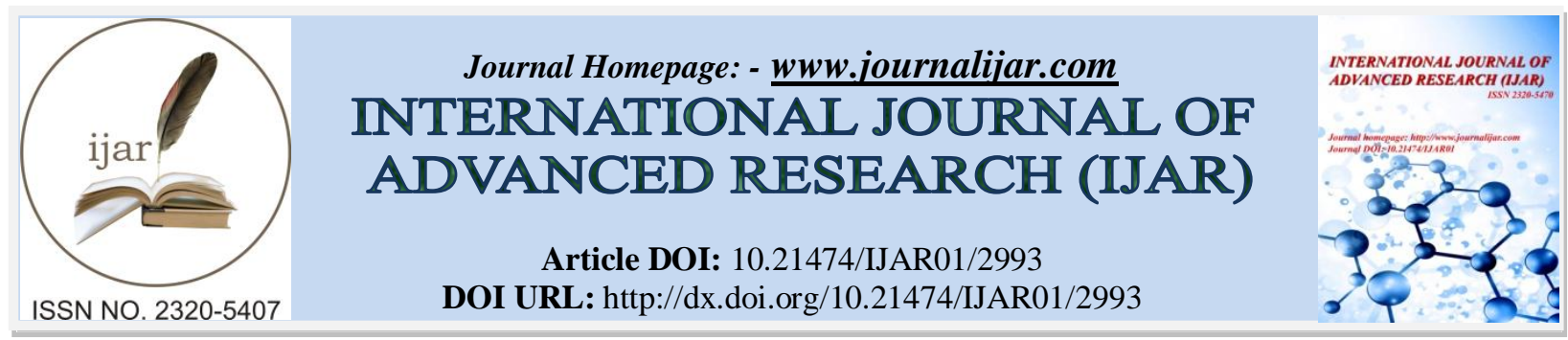

RESEARCH ARTICLE

\title{
PERIPHERAL GIANT CELL GRANULOMA OF ANTERIOR MAXILLA.
}

Dr Gurwinder Kaur ${ }^{1}$ and Dr Atul Soin ${ }^{2}$.

1. Research associate, AHEAD academy,Rajinder Nagar,New Delhi-110059.

2. Professor, Department of prosthodontics, Kalka Dental college, Meerut,U.P

\section{Manuscript Info}

Manuscript History

Received: 28 November 2016

Final Accepted: 27 December 2016

Published: January 2017

Key words:-

Peripheral Giant Cell Granuloma

(PGCG), maxillary anterior, differential diagnosis

\begin{abstract}
Peripheral giant cell granuloma (PGCG) is a benign lesion regarded as a hyperplastic reaction to local injury or chronic trauma, developing only within the oral cavity. The common site for PGCG is the premolar gingival tissue and the crest of the edentulous alveolar ridge. ${ }^{5} \mathrm{PGCG}$ presents as a firm, soft, bright pedunculated or sessile nodule with various sizes: that range from small papules to enlarged masses; though they are generally less than $20 \mathrm{~mm}$ in diameter and is asymptomatic. We describe a 41-year-old male who presented with a peripheral cell giant granuloma of the maxillary anterior area.
\end{abstract}

Copy Right, IJAR, 2016,. All rights reserved.

\section{Introduction:-}

Peripheral giant cell granuloma (PGCG)( giant cell epulis, osteoclastoma, giant cell reparative granuloma, or giantcell hyperplasia) is an infrequent exophytic lesion of the oral cavity occurring on the gingiva and alveolar ridge usually as a result of local irritating factors such as tooth extraction, poor dental restorations, food impaction, ill fitting dentures, and calculus. ${ }^{1}$ Peripheral giant cell granuloma accounts for less than $10 \%$ of all hyperplasic gingival lesions. ${ }^{2}$ PGCG arise interdentally or from the gingival margin, occur most frequently on the labial surface, and may be sessile or pedunculated. ${ }^{1}$ Histopathologically PGCG has a non-encapsulated mass of tissue containing reticular and fibrillar connective tissue containing ovoid or fusiform shaped cells and multi-nucleated giant cells. ${ }^{3}$ We describe a 41-year-old male who presented with a peripheral cell giant granuloma of the maxillary anterior area.

\section{Case History:-}

A 41 years old male complainedof growth in upper front tooth regionsince one and a half years. There was no history of any serious or significant illness.Patient brushed his teeth once daily with tooth paste and medium bristle tooth brush, using horizontal strokes. There was no history of smoking or tobacco chewing.Patient was apparently normal one and a half years ago when he observed a growth in upper front tooth region. The growth was sudden in onset and gradually increased in size to attain the present dimensions. Initially the growth was painless but since 6 months patient reported that the growth bleeds while brushing and pain is associated during brushing only. Patient also feels difficulty in speech.A solitary, sessile, round-ovoid growth with normal mucosal color is present on anterior maxillary gingiva. The growth measured $3 \times 3 \mathrm{~cm}$ approximately (Fig. 1) .On Palpation inspector findings were confirmed. The growth was firm in consistency, slightly rough on surface texture, non-tender on palpation and bleeds on provocation. Gingiva was generalized red and enlarged with generalised loss of stippling and knife edge margins. A provisional diagnosis of Pyogenic granuloma was done.Peripheral ossifying fibroma, Peripheral giant cell fibroma, Gingival hyperplasia and Peripheral giant cell granuloma were also considered in the differential diagnosis.Routine haematological and serological investigations were normal. Radiological examination revealed no evidence of bony involvement (Fig. 2). Histopathological features revealed stratified squamous epithelium overlying 
the connective tissue stroma. The epithelium shows ulcerations in some areas. The underlying mass of fibrillar connective tissue stroma consists of large numbers of plump spindle shaped connective tissue cells and many multinucleated giant cells which contain varying number of nuclei. Some of the giant cells are found in lumina of blood vessels. Numerous capillaries and haemmorragic areas are seen around the periphery of the lesion. The findings were consistent with a diagnosis of Peripheral giant cell granuloma.Patientwas explained about the condition and was reassured. The patient was placed on follow-up.

Figure 1:- Intraoral swelling observed in anterior maxilla.

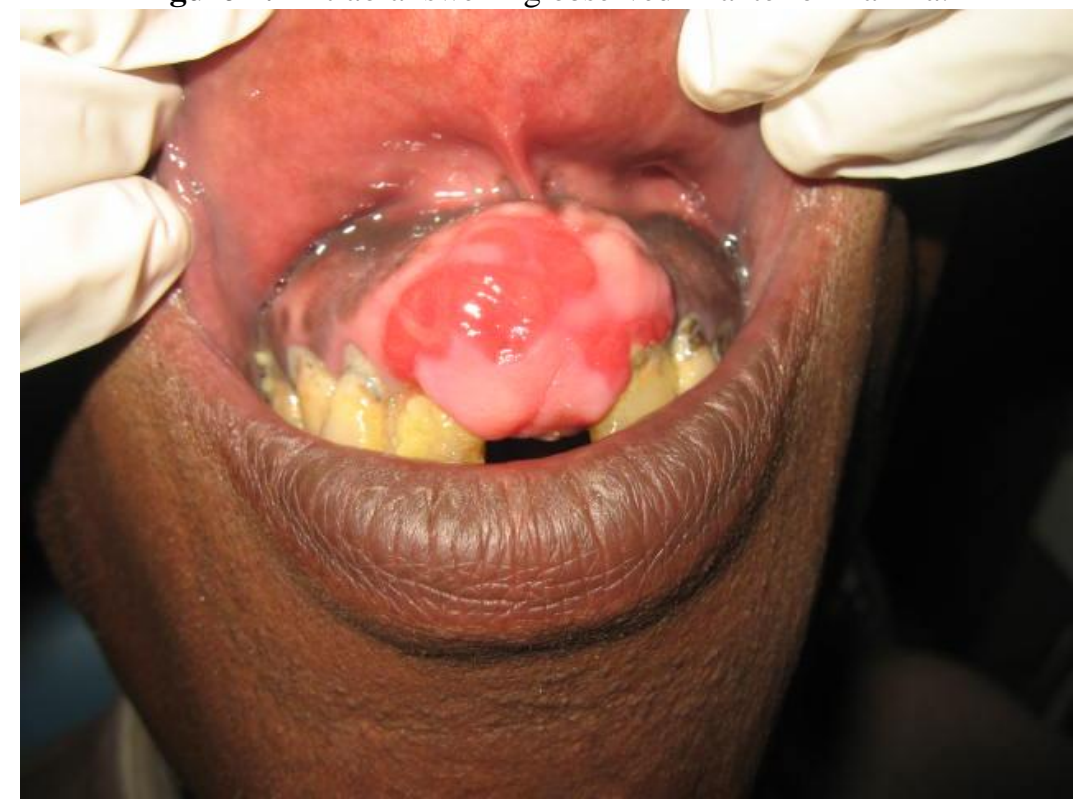

Fig. 2:- Intraoral periapical radiograph showing no abnormal changes
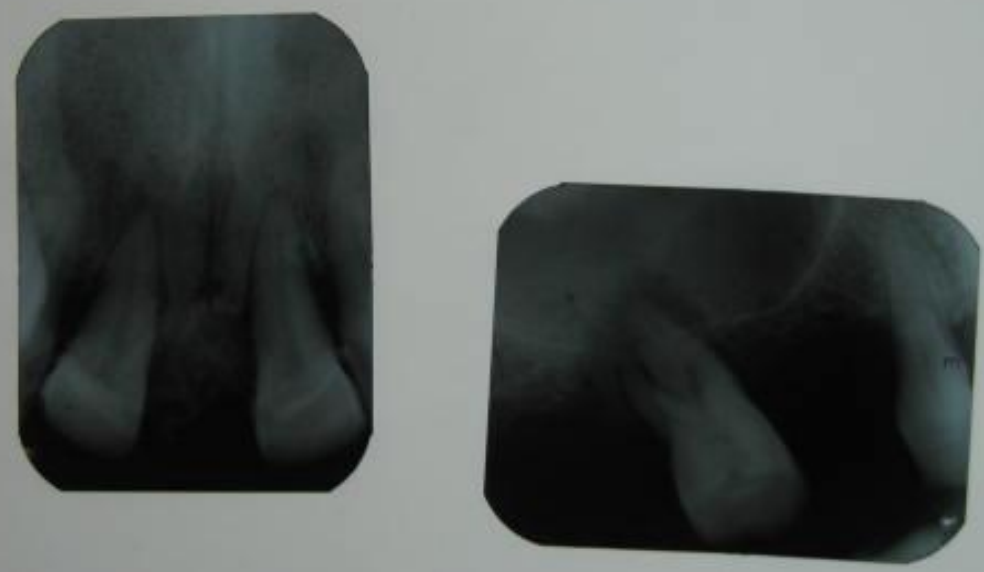
Fig. 3:- Photomicrograph showing focal aggregates of multinucleated giant cells in deeper connective with overlying epithelium. Inset reveals higher power of giant cells. (x40,x400; H\&E)

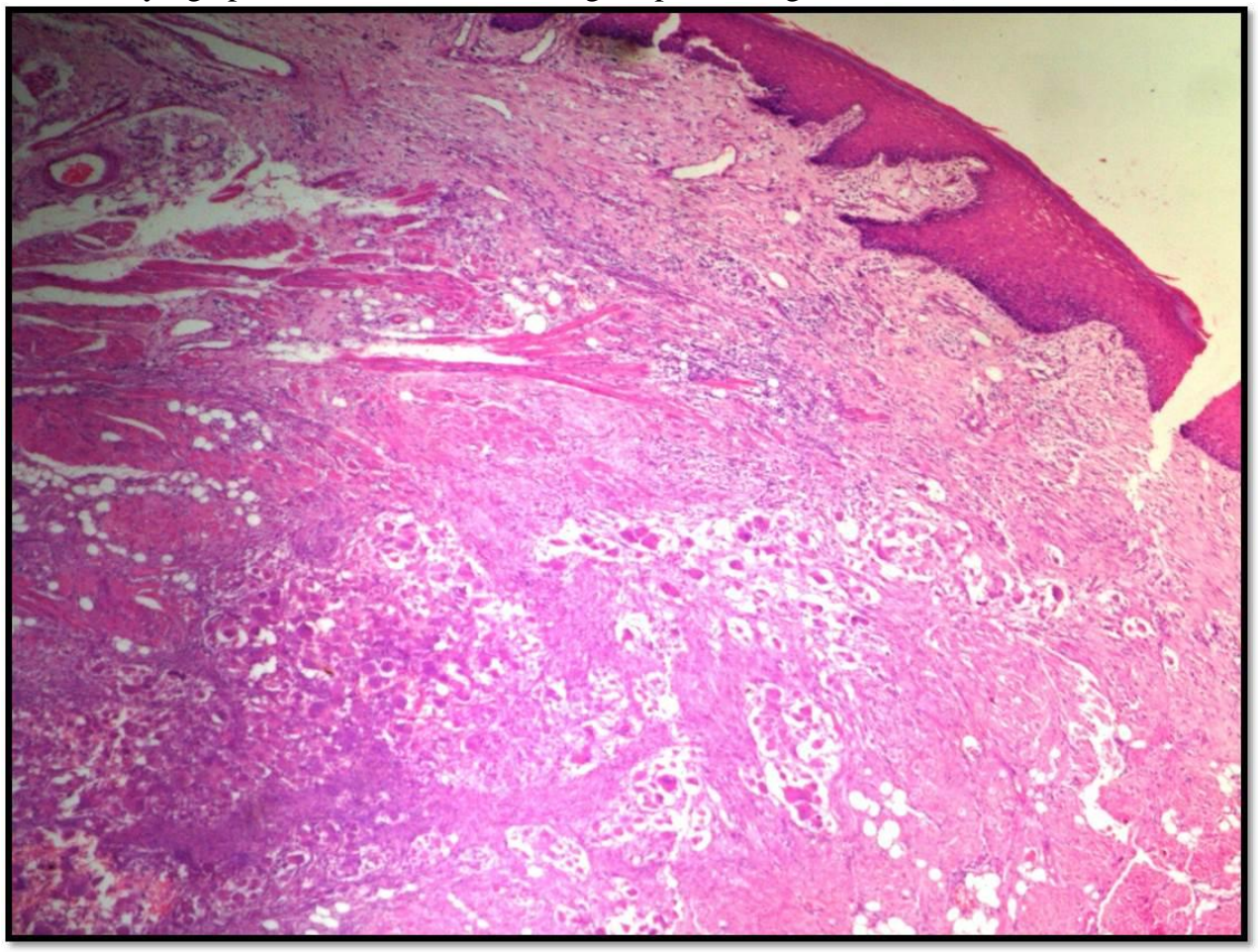

\section{Discussion:-}

PGCGs can occur at any age, but most commonly are noted between the fourth and sixth decades and appear to be more common in women, with the most prevalent site being the posterior mandibular alveolar mucosa. ${ }^{4} \mathrm{PGCG}$ has clinical features which separates it from the fibrous and vascular gingival enlargements. ${ }^{5} \mathrm{PGCG}$ presents as a firm, soft, bright pedunculated or sessile nodule with various sizes: that range from small papules to enlarged masses; though they are generally less than $20 \mathrm{~mm}$ in diameter and is asymptomatic. ${ }^{5}$ The growth of PGCG is generated by repeated trauma. There is a variation in color from dark red to purple or blue commonly with ulcerated surface. ${ }^{4,5}$

The etiology of PGCG is still not precisely defined. Gottsegen suggested the development of PGCG often after periodontal surgery. Local irritating factors such as tooth extraction, poor dental restorations, food impaction, ill fitting dentures, and calculus are often considered predisposing factors for PGCG. Low socioeconomic status of the patients and unfavorable oral hygiene also seem to be predisposing factors to peripheral giant cell granuloma. ${ }^{6}$ Choi had reported the correlation of PGCG with hyperparathyroidism secondary to renal failure. ${ }^{7}$

The differential diagnosis of PGCG includes pyogenic granuloma, fibrous epulis, peripheral ossifying fibroma, inflammatory fibrous hyperplasia, peripheral odontogenic fibroma, and papilloma, all of which present with similar clinical and radiographic findings. ${ }^{8}$ Radiographic examinations typically reveal no findings, because the lesion is a soft tissue mass.PGCG has been found to be more common in the mandible as compared to maxilla. ${ }^{9}$ The reported proportion is 2.4:1 and in most cases, it occurs anterior to molar region. ${ }^{10}$

The treatment of PGCG comprises surgical resection with elimination of the entire base of the lesion and suppression of the etiologic factor. If resection is only superficial, the growth may recur. Most lesions respond satisfactorily to thorough surgical resection, with exposure of all the bone walls. When the periodontal membrane is affected, extraction of the adjacent teeth may prove necessary to insure full resection though this is initially contraindicated. ${ }^{11}$ There are no dissimilarities between cold scalpel or carbon dioxide laser resection of PGCG. The advantages of laser resection are that it causes less intraoperative bleeding, sterilizes the wound, requires no suturing and affords improved postoperative patient comfort.$^{12}$ carbon dioxide laser is of limited applicability in lesions with adjacent bone involvement, where careful surgical curettage is required and laser resection is not indicated in such cases. ${ }^{12}$ Recurrence of PGCG is infrequent, ranges as little as 5-11\% have been reported. ${ }^{5}$ Although incipient lesions 
may bleed and induce minor changes in gingival contour, gradual growth in some cases produces animportant tumor mass that adversely affects normal oral function.

Liu et al concluded that RANKL and OPG expressed in lesions may play on important role in the formation of multinucleated giant cells. ${ }^{13}$ Histopathologic characteristics of PGCG are harmonious with periodontal ligament or periosteumorigin. ${ }^{14}$ The histopathological findings of PGCG is characteristic chiefly due to the considerable quantity of multinucleated giant cells that are scattered in the connective tissue stroma. ${ }^{14}$ Vascular capillaries are profusely available, especially in the peripheral areas, and giant cells are occasionally recognised in the internal wall of these vessels. ${ }^{12}$ Hemorrhagic foci are also observed with the release of hemosiderin pigment and posterior invasion by mononuclear phagocytes and inflammatory cells. ${ }^{15}$ The fibrocellular reaction is similar to that of other reactive lesions such as fibrous hyperplasia and peripheral ossifying fibroma. The calcified material or newly formed bone may also be seen all over the cellular connective tissue, and some of the lesions may be either woven bone or lamellar bone produced by the mononuclear stromal cells, which might be similar to latent proliferative osteoblasts or osteoprogenitor cells. ${ }^{9}$ The exact source or origin of the giant cellsis still uncertain. ${ }^{9}$ Many theories have been proposed in the English literature, as osteoblasts, phagocytes, endothelialcells, and spindle cells are thought tobe responsible for giant cell proliferation. ${ }^{9}$ Thus, in such cases a definitive diagnosis can only be established through histopathological examination.

PGCG is histologically identical to its centralequivalent, the central giant cell granuloma (CGCG)and the brown tumor of hyperparathyroidism . Radiological investigations are hence imperative for diagnosis to confirm that this giant cell lesion arises within the oral mucosa and does not represent a central gnathic lesion with cortical perforation and soft tissue invasion.In conclusion, the timely and accurate diagnosis of PGCG, centred on the clinical and radiographic findings and histopathological study, allows conservative therapy with a minor possibility of less risk for tooth and bone loss for the teeth and adjacent bone.

\section{References:-}

1. Ozcan E,Bodur S, Erdem G. Peripheral giant cell granuloma- a case report. Pak Oral dent J 2011; 31(1); 171-2.

2. Kaya GS, Yalcin E, Tozoglu U, Sipal S, Demirci E. Huge peripheral giant cell granuloma leading to bone resorption: A report of two cases. Cumhuriyet Dent J 2011;14;3:219-224

3. Mannem S, Chava VK. Management of an unusual peripheral giant cell granuloma: A diagnostic dilemma.ContempClin Dent 2012; 3; 93-6.

4. Pirih, F., Barroso, A.D., Tatarakis, N., Cordell, K., McCauley, L. and Edwards, P. A Case Reportof a Peripheral Giant Cell Granuloma in a Patient on Forteo. Open J Stomatolog 2015; 5: 147-151.

5. Abu Gharbyah AZ, Assaf M. Management of a Peripheral Giant Cell Granuloma in the esthetic area of upper jaw: A case report.nt J Surg Case Rep. 2014;5(11):779-82.

6. Eronat N, Aktug M, Glinbay T, Unal T. Peripheral giant cell granuloma: Three case reports. J ClinPediatr Dent 2000;24:245-8. Back to cited text no. 6

7. Choi C, Terzian E, Schneider R, Trochesset DA. Peripheral giant cell granuloma: Associated with hyperparathyroidism secondary to end-stage renal disease: A case report. J Oral MaxillofacSurg 2008;66:10636.

8. Adlakha V K, Chandna P, Rehani U, Rana V, Malik P. Peripheral giant cell granuloma. J Indian SocPedodPrev Dent 2010;28:293-6

9. Etoz OA, Demirbas AE, Bulbul M, Akay E. The peripheral giant cell granuloma in edentulous patients: report of three unique cases. Eur J Dent. 2010 Jul;4(3):329-33.

10. Reichart P, Philipsen H P. Peripheral giant cell granuloma: review of 720 cases. J Oral Surg. 2000:164.

11. Shadman N, Ebrahimi SF, Jafari S, Eslami M. Peripheral giant cell granuloma: a review of 123 cases. Dent Res J (Isfahan). 2009 Spring;6(1):47-50.

12. Chapparro-Avendano AV, Berini-Aytes L, Gay-EscodaC.Peripheral giant cell granuloma .A report of five cases and review of literature . MED ORAL PATOL ORAL CIR BUCAL 2005;10:48-57.

13. Liu B, Yu SF, Li TJ: Multinucleated giant cells in various forms of giant cell containing lesions of the jaws express features of osteoclasts. J Oral Pathol Med 2003; 32(6):367-375.

14. Bodner L, Peist M, Gatot A, FlissDM.Growth potential of peripheral giant cell granuloma. Oral Surg Oral Med Oral Pathol Oral RadiolEndod 1997;83:548- 551.

15. Flaitz CM. Peripheral giant cell granuloma: a potentially aggressive lesion in children. Pediatr Dent 2000;22:232-3. 